UDC 343.979:94(477) «2014/2018»

DOI: $10.24919 / 2519-058 x .7 .130669$

\author{
YURiy SLUSARENKO, \\ orcid.org/0000-0001-6772-4386 \\ Ph D (juridical sciences), Associate Professor of constitutional right \\ Taras Shevchenko Kiev National University \\ (Ukraine, Kyiv) yuanatolievich@ukr.net
}

\title{
LEGAL REGULATION OF ECOLOGICAL SAFETY DURING THE OIL AND GAS EXTRACTION IN UKRAINE
}

The features of the legal regulation of the environment protection during oil and gas extraction in Ukraine at the beginning of the XXI century were analyzed and promising directions of its improvement were defined. The reasons of increasing attention to the extraction of these types of fuel were defined. Measures dependence in the field of ecological safety from legal personality of legal entities in the sphere of oil and gas extraction in Ukraine were discovered. The process of Ukrainian cooperation with Shell and Chevron companies in context of the defining the conditions of the most acceptable for foreign investors, who are planning to invest in oil or gas extraction in Ukraine was highlighted. The process of adapting Ukrainian legislation for interests and needs of investors and with taking onto account the need in providing environmental protection in the process of mining was highlighted. The reasons and the character of the changes of legislation, aimed for deregulation in the oil and gas industry of Ukraine were defined. The influence of economic factors on the changes of legislation character, which regulates the legal relationships that arise in the process of organizing oil and gas production in Ukraine and in the distribution of mined minerals, was analyzed.

Key words: natural gas, oil, legal regulation, legal status, legal personality, gas extraction companies.

Юрій СЛЮСАРЕНКО, кандидат юридичних наук, дочент кафедри конституиійного права Київського наџіонального університету імені Тараса Шевченка (Україна, Київ) yuanatolievich@ukr.net

\section{ПРАВОВЕ РЕГУЛЮВАННЯ ЕКОЛОГІЧНОЇ БЕЗПЕКИ ПІД ЧАС ВИДОБУТКУ НАФТИ ТА ГАЗУ В УКРАЇНІ}

\footnotetext{
Проаналізовано особливості правового регулювання захисту навколишнього середовищча в ході видобутку нафти та газу в Украйні на початку XXI cm. та визначено перспективні напрями його вдосконалення. Визначено причини посилення уваги до видобутку ичи видів палива. Виявлено залежність заходів у сфері екологічної безпеки від правосуб 'єктності юридичних осіб у сфері видобутку нафти та газу в Україні. Висвітлено прочес співробітничтва України із компаніями Shell ma Chevron y контексті визначення умов, найбільш прийнятних для іноземних інвесторів, що планують вкладати кошти у видобутку нафти або газу в Україні. Висвітлено проиес пристосування украӥнського законодавства до інтересів та потреб інвесторів із урахуванням необхідності забезпечення захисту навколишнього середовища у проиесі проведення гірничих робіт. Визначено причини та характер змін законодавства, спрямованих на дерегуляцію у нафтогазовій галузі Украӥни. Визначено вплив економічних чинників на характер змін законодавства, шо регулюе правовідносини, які виникають у процесі організації видобутку нафти та газу в Украӥні та при розподілі видобутих корисних копалин.

Ключові слова: природний газ, нафта, правове регулювання, правовий статус, правосуб'єктність, газовидобувні компанї.
} 
Formulation of the problem. The legislation changes in ecological law sphere in Ukraine at the beginning of XXI century were caused by a number of political and social-economic factors, among which it is worthwhile to highlight the interests of large Ukrainian financial-industrial groups, foreign investors and individuals in international politics who are interested in destabilizing of the situation in Ukraine. As the neo-liberal reforms implementing experience in Ukraine proved, representatives of large financial and industrial groups often preferred to violate legislation if it could provide high profits. There was no exception to the legislation, which regulated various aspects of environmental protection, including the definition of safe rules for the extraction and transportation of oil and gas. The establishment of the «oligarchy» as a combination form of corrupt political power, the shadow economy and the criminal world, and as the nomenclature and corporate clan's domination, made the utilitarian use of democratic norms and procedures possible for oligarchs, so a peculiar symbiosis of the oligarchy and authoritarianism was formed (Рафальський, 2016: 422). One of its consequences was the change in the legislation of Ukraine in favor of large financial and industrial groups. Attempts to change the legislation were motivated by the desire to monopolize the market, to provide favorable conditions for work, including through the neglect of the rules designed to ensure the protection of the environment. At the same time, the development of market relations gradually made adjustments to the activities of financially-industrial groups controlled by the oligarchs, as monopolistic competition in the long run, according to the model of the American economist Paul Krugman, contributes to the reduction of profits up to zero. The development of Ukrainian legislation has had a significant impact from the aggressive actions of the Russian Federation, namely the annexation of the Crimea and the resolution of the war on the Donbas. In order to confront «gas blackmail» on the part of the Russian Federation, Ukraine for some time completely abandoned the purchase of Russian gas, preferring the acquisition of «blue fuel» from European suppliers. This action allowed the Ukrainian side to win a lawsuit against Russia in the Stockholm Arbitration. However, the problem of providing Ukrainian consumers with energy carriers for an adequate price is, up to date, among the main priorities for the government. Thus, a complex of threats now to the energy security of Ukraine has been formed. Many researchers see the overcoming of such threats, firstly, in the natural gas increasing production on the Ukrainian territory. However, the maintenance of environmental safety in the areas of extraction and transportation remains important. Therefore, the analysis of the legal regulation effectiveness of environmental safety during mining operations remains extremely relevant, since in world practice, often in order to increase profits of mining companies the protection of the environment was sacrificed.

The analysis of the last research and publications. In the context of the study of a particular problem, one should note the theoretical developments of A. Matsko (legal protection of employees, implementation of norms of international standards for maintaining law and order in the national legislation of the states), Y. Patsurkivskyi (legal regime of property of subjects of entrepreneurial activity), R. Maydanyk (peculiarities of protection subjective civil rights to immovable property). At the same time, the analysis of the content and procedure for the adoption of the latest regulatory acts (2018) related to the environmental safety protection during the oil and gas extraction, was carried out for the first time.

The purpose of the article: an assessment of the state of the legal regulation of environmental protection during oil and gas production in Ukraine with the definition of the state body's role, including large financial-industrial groups, civil society and territorial communities in this process. 
Description of the main results of the study. For a long time, the regulation of legal relations that arose in the field of oil and gas production in Ukraine was regulated by the Code of Ukraine «On Subsoil» (Про надра, 1994), the Land Code of Ukraine (Земельний кодекс України), the Mining Law of Ukraine (Гірничий закон України), the Laws of Ukraine «On Oil and Gas» (Про нафту і газ, 2001), «On the Regulation of Urban Development» (Про врегулювання), «On Land Management» (Про землеустрій), «On Environmental Expertise» (Про екологічну експертизу), «On Protection of Population and Territories against Manmade and Natural Emergencies» (Про захист населення), «On protection of the environment» (Про охорону). In addition, there were rules of environmental safety, defined by a number of state standards, namely GATS 41-00032626-00-007-97 Environmental protection. Construction of exploration and exploitation wells for oil and gas on land; GATS 41-0032626-00-011-99 Steps and stages of exploration for oil and gas. They also defined the basic rules, which were supposed to ensure environmental safety at oil and gas fields, as well as in the areas where they were transported. However, over the time, the magnitude and methods of gas extraction have been significantly expanded. At the beginning of the XXI century there was a so-called «shale revolution», when leading mining companies mastered deep drilling technologies (about $4000 \mathrm{~m}$ ), which allowed the shale gas extraction. For this purpose, the so-called cracking or hydro-rupture method was used, for which relatively large volumes of water were needed. Their use increased the level of potential threat to the environment, which required improvement of the legal regulation of environmental safety during mining. The first place of its implementation belongs to the United States. The US experience in this area has been widely discussed in the European Union.

In November 2012, the European Parliament refused to extend the moratorium on shale gas extraction. Such a decision was taken under the influence of the «shale revolution» in the United States, where standards for deep drilling were developed. They determined the maximum volumes of methane emissions, limited pollution of reservoirs, groundwater and ground areas on territories where drilling was carried out. Additionally, acceptable levels of compensation to citizens were identified for harming their interests, including the ability to be engaged in economic activity because of the installation and use of mining equipment and pipelines, which are necessary for the mined minerals transportation.

However, the economic opportunities of the world leading countries, and above all the USA, allow us to resort to relatively high costs for environmental cleanliness during drilling operations. On the other hand, leading mining companies are trying to reduce such costs by placing wells in other countries where the interests of the local government, the general poverty of citizens, the unsettled legal relationship associated with environmental threats due to shale gas production, allow you to work without respecting the strict norms of protection of the environment the environment.

Against the background of the complication of relations with the Russian Federation and the use of Russian gas supply and transit through Ukraine to Western European consumers as a means of pressure on the Ukrainian authorities, attempts have been made repeatedly to conclude agreements with foreign companies for developing their Ukrainian gas reserves. The appeal to foreign investors was not necessarily due to the need to use modern drilling equipment and to attract relatively large funds for the organization of work.

At the same time, as the content of the agreements showed, foreign companies were offered a significant reduction of expenditures for carrying out works. In particular, it was also about certain restrictions on compliance with the rules of environmental safety, which 
could cause pollution of the environment. At the same time, the initiative to provide such opportunities for foreign entrepreneurs mainly came from the Ukrainian leadership. It was believed that it would be possible to ensure the foreign investment growth. This approach was potentially dangerous for Ukrainian citizens who lived in those regions where they planned to mine minerals. This, accordingly, caused a negative reaction and protests. At the same time, ordinary citizens were largely unaware of the peculiarities of, for example, shale gas extraction, and often in their actions were driven by emotions or by the influence of interested parties, who at all costs sought to disrupt the expansion of gas production in Ukraine. Against this backdrop, a discussion was held in the scientific community on the possible risks identification to the environment in the event of the gas extraction organization. In debates participated not only economists, but the specialists in the environment sphere, and also political scientists, who wanted to evaluate the opportunities of territorial communities influence for accommodation on theirs territory of drilling stations. The object of the analysis became the current legislation and possible options of its changes. It was repeatedly suggested that the interests of large financial and industrial groups could outweigh the interest of territorial communities in preserving a safe environment. At the same time, it was emphasized on the possibility of using the US's positive experience in complying with environmental safety standards when organizing shale gas production.

The interest of Shell in reducing its cost of production was evident during the conclusion of an agreement on the development of shale gas deposits in Ukraine. One of the biggest problems was the strengthening of the adaptation of Ukrainian legislation to the International Recommended Practice for the exploitation of oil and gas deposits, which means uses and practices that at some point are generally accepted under similar circumstances in the international oil and gas industry. Certification of the main operating facilities was foreseen according to the standards of an internationally recognized independent environmental management system and only if such installations involve significant environmental risks. The removal of technological wastewater and extracted water, as well as the transport and disposal of waste, should take place in accordance with internationally recognized standards. Conducting the assessment and management of the risks of soil and water pollution only concerned their surface parts, except for the monitoring of groundwater. Shell received the right to use water without complying with rational water use rules. The draft agreement with the investor provided for the use of wells for the injection of sewage (Жиравецький та ін., 2013). The agreement with Chevron did not provide the collection of environmental data before the work begin and to analyze its impact on the environment in order to assess possible negative effects (Сланцева угода). Thus, the terms of the shale gas extraction laid in the draft agreement formed a rather high probability of the environmental threat from the chemical substances necessary for the extraction of shale gas, including contamination of groundwater.

In July 2013, a hearing was held at the Committee on Environmental Policy, Environmental Use and Elimination of the Consequences of the Chernobyl Disaster of the Verkhovna Rada (Parliament of Ukraine) on the topic «Environmental problems of shale gas extraction in Ukraine». People's deputies of Ukraine and employees of the Verkhovna Rada, National Security and Defense Council of Ukraine, representatives of the Ministry of Energy and Coal Industry, The State Service of Geology and Mineral Resources of Ukraine, «Bosom of Ukraine», «Naftogaz of Ukraine», National Academy of Sciences of Ukraine, Lviv Oblast Council, Ivano-Frankivsk Regional State Administration, Embassies of the United Kingdom, the Netherlands and the United States in Ukraine, the American Chamber of Commerce in 
Ukraine, the Office of the US Department of Energy in Ukraine, «Shell» and «Chevron», scientists, representatives of non-governmental organizations, mass media and the public had been participating in the hearing. The result of the hearings was the adoption of a decision on the recommendation of the Cabinet of Ministers of Ukraine before the start of work by Shell and Chevron to ensure the organization of a permanent system of environmental monitoring and environmental control of in places of exploration and extraction of shale gas. It provided for control of radiation pollution, the state of drinking water, determination of volumes and sources of water collection for hydro-disruption in contact with local authorities and central executive authorities, etc. It was also planned to build storage facilities for liquid waste and prohibit the transfer of polluted water to wastewater treatment facilities where there is no possibility of neutralizing toxic and radioactive materials. The document also provided for the public ahead of information on the benefits and risks of shale gas development (Екологічні проблеми).

In November 2013, Ukraine signed an agreement on the distribution of hydrocarbons extracted from the "Chevron Ukraine». It was also agreed to conduct geological exploration with «Shell». In November 2014, the Ukrainian side announced the fulfillment of the conditions set for signing an operating agreement with «Chevron». Confirmation of such agreements was expected in mid-December 2014 (Украина ожидает). However, «Chevron» refused to cooperate further, motivating its decision to drop global oil and gas prices. In the context of adopting such a decision it is not necessary to discard possible risks associated with the continuation of the war on the Donbass.

However, the economic attractiveness of gas production in Ukraine has forced to continue work in this direction. The problem was aggravated also in connection with the continuation of the «gas confrontation» with Russia, whose leaders have repeatedly expressed their opposition to the implementation of the Stockholm arbitration, and in March 2018 the Russian side appealed. At the same time, the position of the Ukrainian side required intensification. During 1991 - 2017 Ukraine reduced the volume of gas consumption and the extent of its purchases in Russia. So, if in 1991 it was used $118.2 \mathrm{~m} 2$, then in $2017-31.9 \mathrm{~m} 2$, if in 1991 91.6 billion $\mathrm{m} 2$ of gas were imported, then in 2017 only 14.1. The least gas was imported in 2016 - only 11.1 billion m2. From 2013 Ukraine began to buy gas in Poland, Hungary, Slovakia, and from November 2015 Ukraine stopped purchasing gas in Russia (Импорт газа).

In February 2018, the Prime Minister of Ukraine V. Groysman expressed the opinion that in a few years the increase in gas production in Ukrainian deposits would allow a gradual reduction of its prices for the population. Moreover, earlier, the ex-prime minister A. Yatsenyuk argued about enough gas that was extracted in Ukraine to meet the needs of the population. The sharp rise in gas prices for the population, whose solvency remained relatively small, was one of the reasons for the accumulation of debts for gas and heat supply to ordinary consumers. Cross-subsidization, in which the tariffs for gas supplied to industrial consumers grew by their unchanged for the population, proved to be ineffective, as the growth of tariffs was set at the price of industrial goods. Subsidizing the population to pay higher bills for gas was also ineffective because it remained non-addressable. It actually only increased the profits of large financial-industrial groups by transferring them from public funds within the framework of subsidizing the population. At the same time, a significant part of those who received subsidies was not interested in saving energy, since it counted exclusively on the subsidy. This forced the government to reconsider the conditions for subsidies due to its reduction. At the same time, the absence of large-scale state measures in the area of insulation 
of residential buildings and the deterioration of the heating networks, as well as the lack of local attention to the use of alternative energy sources, were an obstacle to further reduction of gas consumption. At the same time, the reduction of its consumption took place over the last few years due to the loss of control over part of the territory of the Donbas and the Crimea, and this can not be attributed to the merits of the Ukrainian governments.

Against this backdrop, it was proposed to amend the legislation to facilitate gas extraction. Draft bill No. 3096-d was prepared, which provided for the simplification of some aspects of the oil and gas industry. At that, important changes were foreseen precisely in the field of ensuring environmental safety. So, to Article 97 of the Land Code of Ukraine (Земельний кодекс України) it was proposed to amend part 6 where it was argued that during the transition from the state of experimental-industrial development to industrial development for enterprises, establishments and organizations conducting exploration works, it is permitted to use a land plot on the basis of an agreement on conducting reconnaissance works with the land owner or with the consent of the land user for the period of execution of documents certifying the right to use it. In fact, this would allow agreements with land owners to be concluded, which would greatly simplify the procedure for obtaining the right to carry out works. Article 99 of the Land Code, which referred to the types of rights of land servitude (right to walk and travel on bicycles, travel along the existing route and the right to place temporary structures) was supplemented with the right to construct and deploy oil and gas extraction facilities and placement of pipeline facilities. At the same time, according to the changes that were proposed to make to Article 156 for the needs of the oil and gas industry allowed the use of agricultural land. And thanks to the changes made to Article 168, which allowed the movement of soils for drilling and construction of oil and gas wells, construction, maintenance, repair and reconstruction of oil and gas wells and associated facilities, pipeline transport, production facilities, access roads, lines power transmission and communication, underground cable power supply networks. As well as for work related to the liquidation and prevention of oil and gas wells and associated emergencies their operation sites of pipelines, production facilities, access roads, power lines and communication networks of underground power cable. At that, Article 168 of the Land Code of Ukraine prohibited the movement of soils without the special permission of the central executive authority, which implements the state policy in the sphere of implementation of state supervision (control) in the agro-industrial complex. Thus, the need to coordinate the movement of soils with the profile ministry was eliminated.

An extremely important task for ensuring environmental safety was the introduction of the Code of Ukraine «On Subsoil» (Про надра, 1994) Article 17, where it was a question of mining removal. Mining was determined part of the subsoil, provided to users for the industrial development of mineral deposits and purposes not related to the extraction of minerals. The use of subsoil outside the mining area was prohibited. At the same time, mining pits for the development of mineral deposits of national importance, the construction and operation of underground structures and other purposes not related to the extraction of minerals, were to be provided exclusively by the central executive body, which implements state policy in the field of labor protection. However, thanks to the changes introduced, users of oil and gas subsoil who received special permits for the use of such subsoil do not require mining. In fact, mining companies were able to exploit subsoil without clearly defined boundaries of the mine, which potentially carries a significant risk of soil contamination.

To facilitate the extraction of oil and gas by Article 18 of the Law of Ukraine «On Oil and Gas» (Про нафту і газ, 2001) should have been supplemented by establishing in it the 
rights of holders of special permits for the use of oil and gas minerals for the construction, placement and exploitation of oil and gas extraction facilities and arrangement of deposits by land plots of all forms of ownership and all categories without changes in the purpose of these land plots, except for the lands of the nature reserve fund, recreational purposes, recreational appointment, historical and cultural destination and water fund. The right to use such plots was acquired by establishing land easements. It is important that eliminating the need to comply with the requirements of the legislation on changing the purpose of the land significantly simplified the implementation of mining operations, but also involved potential threats of soil pollution, or even the creation of conditions for the impossibility of their subsequent use by previous users or owners. At the same time, it seems rather doubtful that individual landowners will be able to obtain appropriate reimbursement in Ukrainian realities through litigation with powerful oil and gas companies.

At the same time, the proposed amendments to the Law of Ukraine «On Oil and Gas» (Про нафту і газ, 2001) determined the actual responsibility of the central bodies for environmental protection in the conditions of mining operations. Article 36 was to be supplemented with the definition that the industrial development of the deposit is carried out after the submission by the user of oil and gas mines copies of the technological project (schemes) of industrial development of the deposit and copies of the complex project of its arrangement to the central executive authority, which implements state policy in the field of geological study and rational use of subsoil.

In May 2017, the Mining Law of Ukraine was amended to supplement Article 22, where it was determined that the environmental impact assessment and examination were carried out in order to determine the absence of an unacceptable risk associated with the possibility of causing any damage to the life, health and property of citizens, as well as the natural environment and objects of management and Aricle 24 the mandatory presence of a mining outlet for mining operations was determined (Гірничий закон України).

And already in late March 2018, the President of Ukraine signed the Law of Ukraine «On Amendments to Certain Legislative Acts of Ukraine Concerning Deregulation in the Oil and Gas Industry» adopted by the Parliament as a whole on March 1 (Про внесення змін). It is important that in it the possibility of land removal for the needs of oil and gas companies was foreseen solely on the basis of a working project of land management. In addition, this Law excludes the definition of «mining exclusion» from the Law of Ukraine «On Oil and Gas». Instead, several new terms were introduced. Thus, objects of oil and gas extraction included objects intended for geological study, including experimental and industrial development and extraction of hydrocarbons. Oil and gas production facilities were supposed to include oil and gas wells, gas pipelines, gas preparation complexes, gas preparation units, pre-gas preparation plants, integrated oil preparation facilities, temporary pilot and industrial plants for oil and gas preparation, compressor stations and other objects connected with exploitation of oil and gas facilities. The term «arrangement of the deposit» was defined as a complex of design, surveying, construction and other works that should be carried out for the introduction of the deposit into industrial (experimental and industrial) development, or construction, overhaul, reconstruction and technical re-equipment on operating (equipped) fields. Definition of «exploration works» was provided as geological surveying, exploration, geodetic works, geological exploration of oil and gas bearing depths; work on exploration and exploration of deposits. That is including drilling, arrangement and operation of oil and gas wells, for new construction, maintenance, major overhaul and reconstruction of oil and gas wells and asso- 
ciated facilities, pipeline transport, industrial facilities, access roads, electric power lines chi and communication. Thus, the Law «On Amendments to Certain Legislative Acts of Ukraine Concerning Deregulation in the Oil and Gas Industry» envisaged a further simplification of the organization of oil and gas extraction in comparison with the previous draft laws of Ukraine in this area.

At the same time, according to the Law of Ukraine «On Amendments to Certain Legislative Acts of Ukraine Concerning Deregulation in the Oil and Gas Industry» Part 3 of Article 14 of the Law of Ukraine «On Oil and Gas» provided some changes. It has to be worded as follows: «the granting of special permits for the extraction of oil and gas (industrial development of deposits) is carried out taking into account the results of environmental impact assessment». However, the nature of taking into account such results and the dependence of obtaining permits for mining operations in the long-term perspective has not been determined.

At the same time, under pressure from the European Union, Ukraine adopted an important Law on Securing Transparency in the Extractive Industries, which defined the legal framework for regulating and organizing the collection, disclosure and dissemination of information in order to ensure transparency and prevention of corruption in the extractive industries in Ukraine. It also provided for the provision to the public of access to complete and objective information on payments by business entities operating in the extractive industries in favor of payment receivers, creating prerequisites for publicly responsible use of such entities of national importance. As well as for public awareness and discussion of issues related to the use and management by the state and territorial communities of useful minerals of national importance. Thus, representatives of territorial communities were given an opportunity to respond to potential environmental threats, which became possible due to mining.

Conclusion. An analysis of changes in the legislative acts of Ukraine related to the regulation of environmental safety during the extraction of oil and gas, suggests that among such changes are potentially dangerous for the protection of the environment. Yes, it is doubtful that expanding the possibilities for removing and moving the soil during gas production will not lead to abuses, which will result in damage to large volumes of land, including agricultural land. Abuse is also possible in the allocation of land for mining. The possibility of concluding agreements directly with their own can be a reason to ignore the general interests of territorial communities. The absence of the need to determine the boundaries of the mining drainage may also entail the danger of uncontrolled pollution of the subsoil. The obligation to inform local residents about mining operations does not mean eliminating opportunities for abuse in the field of environmental safety, because of lack of awareness of citizens with the specifics of carrying out works, or through knowingly incomplete or inaccurate information about the nature of their conduct. Moreover, taking into account the results of environmental impact assessment when granting special permits for the use of oil and gas subsoil does not guarantee that, it will be carried out of such possible consequences to the fullest extent possible.

\section{BIBLIOGRAPHY}

Гірничий закон України - Гірничий закон України. URL: http://zakon2.rada.gov.ua/laws/ show/1127-14.

Екологічні проблеми - Екологічні проблеми видобування сланцевого газу в Україні / Piшення комітету 3 питань екологічної політики, природокористування та ліквідації наслідків Чорнобильської катастрофи. URL: http://komekolog.rada.gov.ua/komekolog/control/uk/publish/ article?art_id=50631\&cat_id=47174. 
Жиравецький та ін., 2013 - Жиравецький Т. М., Кравченко О. В., Проць Б. Г., Харкевич В. В., Хомечко Г. І. Розвідка та видобуток сланцевого газу: соціальні, правові та екологічні виклики (короткий огляд питання). Львів, 2013. 56 c. URL: http://www.uk.xlibx.com/4yuridicheskie/99400-8rozvidka-vidobutok-slancevogo-gazu-socialni-pravovi-ekologichni-vikliki-korotkiy-oglyad-korotkiyoglyad-lviv.php.

Земельний кодекс України - Земельний кодекс України // Відомості Верховної Ради України. 2002. № 3-4. Ст. 27.

Импорт газа - Импорт газа: сколько голубого топлива Украина закупила с 1991 года. URL: https://ru.slovoidilo.ua/2018/03/09/infografika/jekonomika/import-gaza-skolko-golubogo-toplivaukraina-zakupila-1991-goda.

Про внесення змін - Про внесення змін до деяких законодавчих актів України щодо дерегуляції в нафтогазовій галузі / Закон України. URL: http://zakon5.rada.gov.ua/laws/show/2314-19.

Про врегулювання - Про врегулювання містобудівної діяльності / Закон України. URL: http:// zakon5.rada.gov.ua/laws/show/3038-17.

Про екологічну експертизу - Про екологічну експертизу / Закон України. URL: http://zakon3. rada.gov.ua/laws/show/45/95-\%D0\%B2\%D1\%80.

Про захист населення - Про захист населення і територій від надзвичайних ситуацій техногенного та природного характеру / Закон України. URL: http://zakon2.rada.gov.ua/laws/show/1809-14.

Про землеустрій - Про землеустрій / Закон України. URL: http://zakon3.rada.gov.ua/laws/ show/858-15.

Про надра, 1994 - Про надра / Кодекс України // Відомості Верховної Ради України. 1994. № 36, Ст. 340 .

Про нафту і газ, 2001 - Про нафту і газ / Закон України // Відомості Верховної Ради України. 2001. № 50. Ст. 262.

Про охорону - Про охорону навколишнього природного середовища / Закон України. URL: http://zakon2.rada.gov.ua/laws/show/1264-12.

Рафальський, 2016 - Рафальський I. Національно-державне самовизначення України: внутрішні чинники та зовнішні впливи. Київ: ІПіЕНД ім. І. Ф. Кураса НАН України; Ніжин: Видавець ПП Лисенко М. М., 2016. 480 с.

Сланцева угода - Сланцева угода № 2. Текст УРП з Chevron. URL: http://www.epravda.com. ua/publications/2013/06/12/379523/.

Украина ожидает - Украина ожидает подписания газового соглашения с Шеврон. URL: http:// biz.liga.net/ekonomika/tek/novosti/2890628-ukraina-ozhidaet-podpisaniya-gazovogo-soglasheniya-schevron-.htm.

\section{REFERENCES}

Hirnychyi zakon Ukrainy - Hirnychyi zakon Ukrainy. [Mining Law of Ukraine]. URL: http://zakon2.rada.gov.ua/laws/show/1127-14 [in Ukrainian]

Ekolohichni problemy - Ekolohichni problemy vydobuvannia slantsevoho hazu v Ukraini [Environmental problems of shale gas extraction in Ukraine] / Rishennia komitetu $\mathrm{z}$ pytan ekolohichnoi polityky, pryrodokorystuvannia ta likvidatsii naslidkiv Chornobylskoi katastrofy. URL: http://komekolog.rada.gov.ua/komekolog/control/uk/publish/article?art_id=50631\&cat_id=47174 [in Ukrainian]

Zhyravetskyi ta in., 2013 - Zhyravetskyi T. M., Kravchenko O. V., Prots B. H., Kharkevych V. V., Khomechko H. I. Rozvidka ta vydobutok slantsevoho hazu: sotsialni, pravovi ta ekolohichni vyklyky (korotkyi ohliad pytannia) [Exploration and extraction of shale gas: social, legal and environmental challenges (brief overview of the issue)]. Lviv, 2013. 56 s. URL: http://www.uk.xlibx. com/4yuridicheskie/99400-8-rozvidka-vidobutok-slancevogo-gazu-socialni-pravovi-ekologichnivikliki-korotkiy-oglyad-korotkiy-oglyad-lviv.php [in Ukrainian]

Zemelnyi kodeks Ukrainy - Zemelnyi kodeks Ukrainy [Land Code of Ukraine] // Vidomosti Verkhovnoi Rady Ukrainy. 2002. № 3-4. St. 27 [in Ukrainian]

Import gaza - Import gaza: skolko golubogo topliva Ukraina zakupila s 1991 goda [Import of gas: how many blue fuel Ukraine purchased from 1991]. URL: https://ru.slovoidilo.ua/2018/03/09/ 
infografika/jekonomika/import-gaza-skolko-golubogo-topliva-ukraina-zakupila-1991-goda [in Russian]

Pro vnesennia zmin - Pro vnesennia zmin do deiakykh zakonodavchykh aktiv Ukrainy shchodo derehuliatsii v naftohazovii haluzi [On amendments to certain legislative acts of Ukraine concerning deregulation in the oil and gas industry] / Zakon Ukrainy. URL: http://zakon5.rada.gov.ua/laws/ show/2314-19 [in Ukrainian]

Pro vrehuliuvannia - Pro vrehuliuvannia mistobudivnoi diialnosti [On regulation of urban development] / Zakon Ukrainy. URL: http://zakon5.rada.gov.ua/laws/show/3038-17 [in Ukrainian]

Pro ekolohichnu ekspertyzu - Pro ekolohichnu ekspertyzu [About ecological expertise] / Zakon Ukrainy. URL: http://zakon3.rada.gov.ua/laws/show/45/95-\%D0\%B2\%D1\%80 [in Ukrainian]

Pro zakhyst naselennia - Pro zakhyst naselennia i terytorii vid nadzvychainykh sytuatsii tekhnohennoho ta pryrodnoho kharakteru [On protection of population and territories from emergencies of anthropogenic and natural character] / Zakon Ukrainy. URL: http://zakon2.rada.gov.ua/laws/ show/1809-14 [in Ukrainian]

Pro zemleustrii - Pro zemleustrii [About the land system] / Zakon Ukrainy. URL: http://zakon3. rada.gov.ua/laws/show/858-15 [in Ukrainian]

Pro nadra, 1994 - Pro nadra [About subsoil] / Kodeks Ukrainy // Vidomosti Verkhovnoi Rady Ukrainy. 1994. № 36, St. 340 [in Ukrainian]

Pro naftu i haz, 2001 - Pro naftu i haz [About oil and gas] / Zakon Ukrainy // Vidomosti Verkhovnoi Rady Ukrainy. 2001. № 50. St. 262 [in Ukrainian]

Pro okhoronu - Pro okhoronu navkolyshnoho pryrodnoho seredovyshcha [About the protection of the environment] / Zakon Ukrainy. URL: http://zakon2.rada.gov.ua/laws/show/1264-12 [in Ukrainian]

Rafalskyi, 2016 - Rafalskyi I. Natsionalno-derzhavne samovyznachennia Ukrainy: vnutrishni chynnyky ta zovnishni vplyvy [National self-determination of Ukraine: internal factors and external influences]. Kyiv: IPiEND im. I. F. Kurasa NAN Ukrainy; Nizhyn: Vydavets PP Lysenko M. M., 2016. 480 p. [in Ukrainian]

Slantseva uhoda - Slantseva uhoda № 2 [Slate agreement № 2]. Tekst URP z Chevron. URL: http://www.epravda.com.ua/publications/2013/06/12/379523/ [in Ukrainian]

Ukraina ozhidaet-Ukraina ozhidaet podpisaniya gazovogo soglasheniya s Shevron [Ukraine expects to sign a gas agreement with Chevron]. URL: http://biz.liga.net/ekonomika/tek/novosti/2890628ukraina-ozhidaet-podpisaniya-gazovogo-soglasheniya-s-chevron-.htm [in Russian]

Стаття надійшла до редакиіï 6.04.2018 p. 